\title{
A NEW AND STRIKING ODONTOGLOSSUM (ORCHIDACEAE: ONCIDIINAE) FROM PERU
}

\author{
Stig DalströM ${ }^{1,3} \&$ Saul Ruíz Pérez ${ }^{2}$ \\ ${ }^{1} 2304$ Ringling Boulevard, unit 119, Sarasota FL 34237, U.S.A. \\ Lankester Botanical Garden, University of Costa Rica, Cartago, Costa Rica \\ and National Biodiversity Centre, Serbithang, Bhutan \\ ${ }^{2}$ Allamanda 142, Surco, Lima 33, Peru \\ ${ }^{3}$ Corresponding author: stigdalstrom@juno.com
}

\begin{abstract}
A new species of Odontoglossum with an extraordinary long column and filamentose lip callus is described, illustrated with a photograph and a line drawing, and compared with similar and presumably closely related species, such as $O$. epidendroides and $O$. juninense. The new species belongs to the Odontoglossum complex with a flexible lip-base attachment, but differs from all other species in that complex primarily by the elongate base of the column, below the attachment of the strap-like lip-base.
\end{abstract}

Key words: Oncidiinae, Odontoglossum, new species, Pasco, Peru, taxonomy

In the accompanying text to the plate of Odontoglossum wattianum Rolfe, which was published in Reichenbachia (Sander 1892), we can read: "It is a great thing now-a-days to be able to introduce species of Odontoglossums absolutely new to science. Years ago, when the wilds of Columbia were more untrodden than they are now, we found less difficulty, but year by year such prizes get rarer. The time is not far distant when home skill in hybridization will have to supply novelties in Odontoglossums."

This quote illustrates an often heard opinion about the scarce possibilities of finding new species of Odontoglossum (treated as Oncidium by some authors, see below). Even today experienced "orchid hunters" seem to think that there is not much more to discover when it comes to this attractive genus. But this has been proven to be a hasty conclusion thanks to the discovery of several new species in later years (Dalström 1993, 1996, 1999, 2010, 2012b, 2013) although in honesty, it must be said that Odontoglossum taxonomy needs some special effort to be understood properly. This also appears to be one of the main reasons why genera Cochlioda Lindl., Odontoglossum Kunth, Sigmatostalix Rchb.f. and Solenidiopsis Senghas were transferred to Oncidium (Chase et al. 2008, 2009). This transfer may well have been allowed by molecular analysis but the argument that few people can separate an Odontoglossum from an Oncidium Sw., which has been heard in subsequent discussions, is not really true once you become more familiar with these plants.

The first author of the present paper has outlined an alternative taxonomic treatment (Dalström 2012a), which explains why keeping a slightly enlarged genus Odontoglossum is preferable, and also how to separate this genus from Oncidium based on a combination of morphological, ecological and geographical characteristics. This is supported by the same molecular evidence used by Chase et al. (2009) in their transfer of Odontoglossum species to Oncidium. Another argument that has been heard in the debate about how to best treat these orchids is that many new names have to be created for various smaller groups of plants if we want to keep Odontoglossum as a valid genus. However, the only new names that eventually may have to be created concern two smaller groups of species (here referred to as the 'boothianum clade' and the 'chrysomorphum clade' respectively) that for some intriguing reasons are placed near the base of the larger Odontoglossum clade. In contrast to using this as an argument for lumping all concerned taxa into a large 'waste basket' Oncidium, we believe that this is really a strong reason to do the opposite and further study these smaller clades in order to find out why they are placed where they are.

Morphological analysis of the species in the $O$. boothianum and $O$. chrysomorphum clades show 

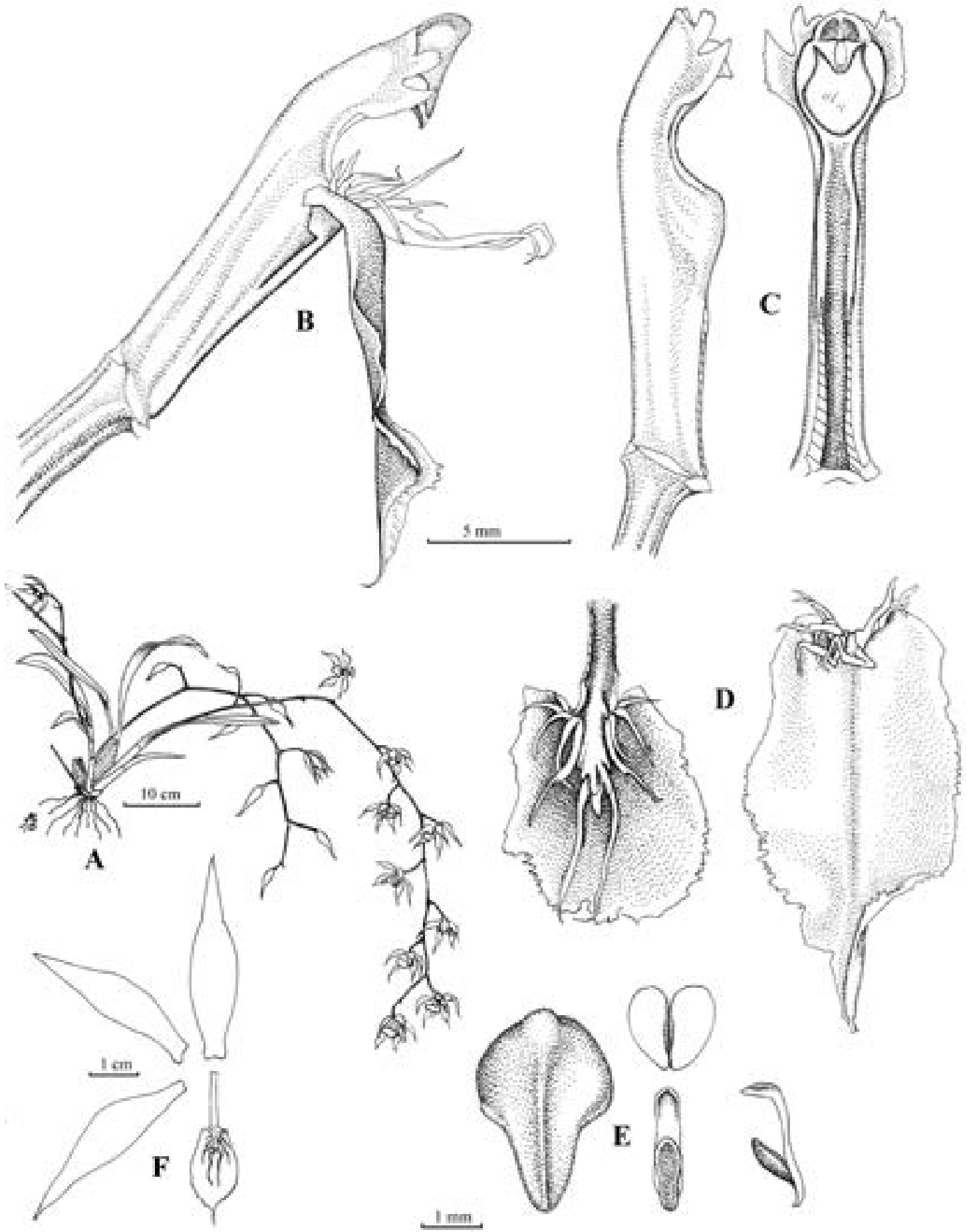

Figure 1. Odontoglossum filamentosum. A - Plant habit. B - Column and lip lateral view. C - Column lateral and ventral views. D - Lip dorsal and frontal views. E - Anther cap frontal view, and pollinarium ventral and lateral views. F Flower dissected. Drawn from the plant that served as holotype by S. Dalström. 
some interesting and distinctive features, such as the compressed, glossy and often purple-mottled, unifoliate pseudobulbs, that seem intermediate between some species of Odontoglossum sensu strictu, and species from some 'Oncidium sensu lato' clades, particularly the clade that produce aborted flowers (here referred to as species of Heteranthocidium Szlach., Mytnik \& Romowicz, also known as the 'Oncidium abortivum group'). Some of the species in the chrysomorphum clade also produce aborted flowers occasionally, in addition to displaying morphological similarities in the pollination apparatus (column, rostellum and pollinarium shapes primarily) to species in the Heteranthocidium complex. Since many Heteranthocidium species grow together and flower simultaneously with many Odontoglossum species, while more 'typical' Oncidium species do not, the possibilities of ancient natural hybridization seem plausible, which may explain the origin and placement of this clade. Plants in the boothianum clade also show similar intermediate features and only marginally differ from the chrysomorphum clade. The fact that these two smaller groups occur one after the other near the base of the Odontoglossum clade may perhaps be the result from several occasions of ancient natural hybridization. These speculations, however, should not be taken for anything other than just that at this time, but rather than to close the door (and settle the debate) to a deeper understanding of the evolution of these orchids, they should be seen as encouragements to further studies.

Although many Odontoglossum species may appear superficially similar, the one described here does not need any particular effort to be recognized as new and different. It is characterized by a unique combination of morphologic features such as the elongated column together with the extremely long and irregularly filamentose callus teeth on the lip, which readily set it apart from its closest relatives; O. epidendroides Kunth (Fig. 3), and O. juninense. Schltr (Fig 4).

Odontoglossum filamentosum Dalström \& RuízPérez, sp. nov. Figs. 1-3.

TYPE: Peru. Pasco: Exact locality unknown but recent observations suggest that the true origin is somewhere near the town of Oxapampa. The type plant flowered in cultivation 10 Feb. 2013, G. Deburghgraeve 282 (holotype: W).

Diagnosis: Odontoglossum filamentosum differs from the similar $O$. epidendroides Kunth (Fig. 3), and $O$. juninense Schltr. (Fig. 4), by the unique combination of the elongated column, $c a .1 .7 \mathrm{~cm}$ long versus $c a$. $1.0-1.1 \mathrm{~cm}$ (O. epidendroides), and $c a .1 \mathrm{~cm}(O$. juninense) together with the extremely long and filament-shaped callus on the lip, versus much less devloped and shortly digitate to curved and spinose callus teeth for the others.

Epiphytic herb. Pseudobulbs caespitose, oblong ovoid, bifoliate, $c a$. $5-8 \times 2-3 \mathrm{~cm}$, surrounded basally by 6 to 8 distichous sheaths, the uppermost foliaceous. Leaves subpetiolate, conduplicate, elongate elliptic to obovate, narrowly acute to shortly acuminate, 19-27 $\times 2.0-3.3 \mathrm{~cm}$. Inflorescences 1 to 3 , axillary from the base of the uppermost sheaths, arching to subpendent, loosely flowered, flexuous, few to many flowered racemes or loosely paniculate with few basal fewflowered side-branches, to $c a .60 \mathrm{~cm}$ long; bracts $0.5-1.3 \mathrm{~cm}$ long. Pedicel with ovary $2.5-3.5 \mathrm{~cm}$ long. Flower stellate to slightly campanulate and rather arachnoid; dorsal sepal yellow almost covered with large brown spots, subunguiculate, elliptic to ovate, acuminate, $c a .4 .4 \times 1.0 \mathrm{~cm}$; lateral sepals similar in color, slightly obliquely elliptic, narrowly acute, $c a$. $4.5 \times 1.1 \mathrm{~cm}$; petals similar in color but less brown, obliquely elliptic, acuminate, $c a .3 .8-4.0 \times 1.0 \mathrm{~cm}$; lip basally pale yellow with a large brown spot covering most of the lamina, and with a pale yellow to white edge, unguiculate, adnate to the base and lateral flanks of the column by a linear $c a .8 \mathrm{~mm}$ long claw/unguis, then free, developing very short, erect sidelobes, abruptly plicate and laminate, indistinctively cordate, obovate to oblong pandurate, apical part of lamina more or less concave, erose to fimbriate, apically slightly canaliculate or convolute, acuminate, $c a .3 .0-3.4 \times 1.0$ cm; callus white, of a low, median, longitudinal, fleshy, glabrous keel, emerging from the base and extending to the lamina where it develops into a series of spreading, more or less falcate, narrowly denticulate to spinose, or filamentose keels, with a larger, multi-lacerate and filamentose, laterally compressed projecting pair in the middle, with a small tooth in between; column basally pale green, then white with some brown marking near 


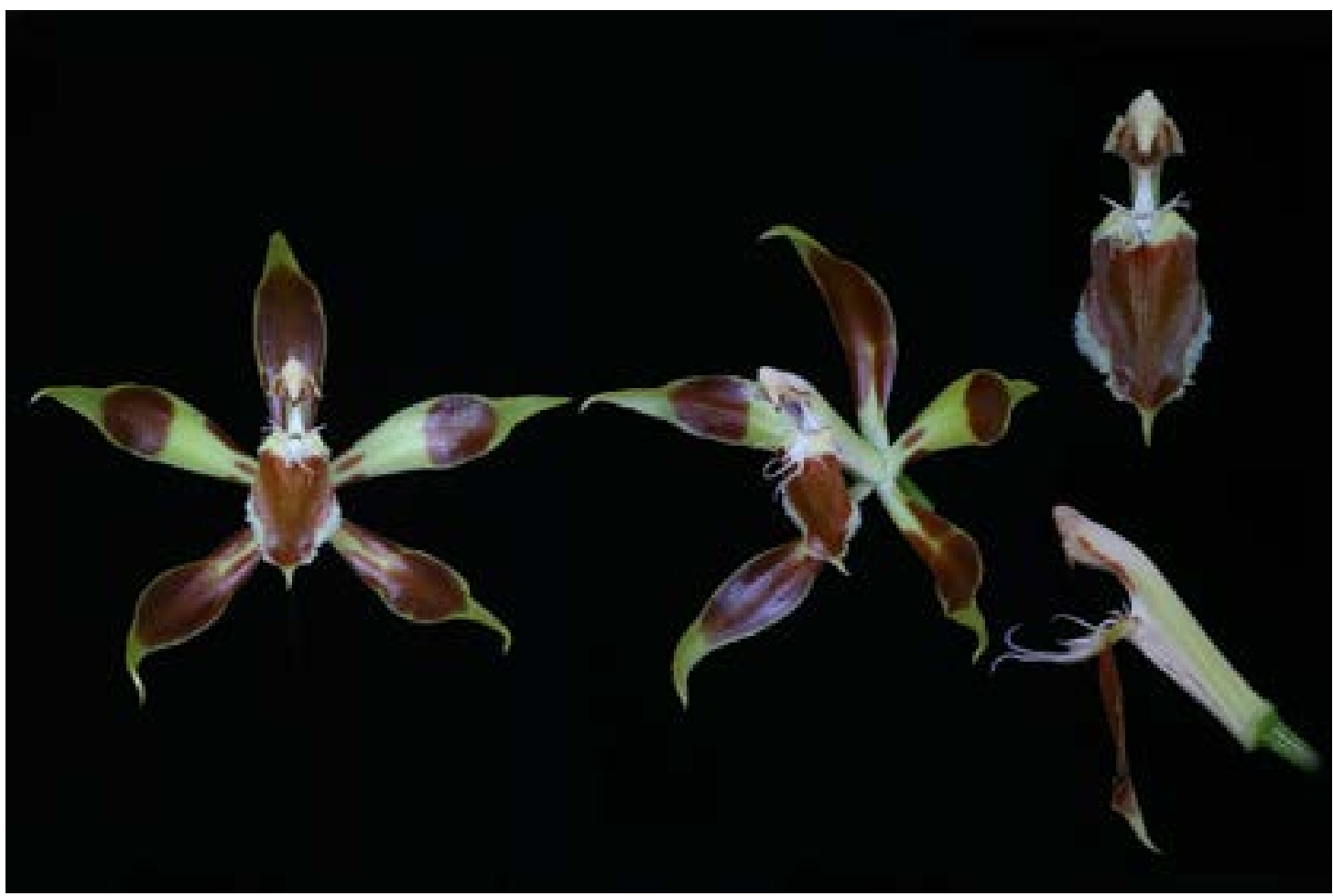

FIgURE 2. Odontoglossum filamentosum, floral diagram (G. Deburghgraeve 282). Photo: G. Deburghgraeve.

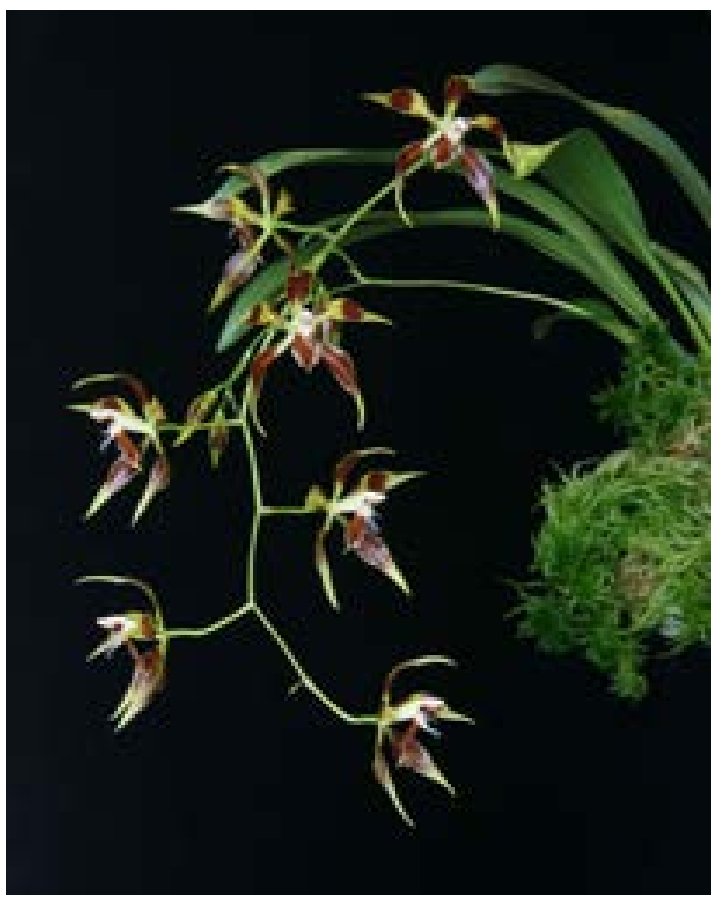

FIGURE 3. Odontoglossum filamentosum, plant habit ( $G$. Deburghgraeve 282). Photo: G. Deburghgraeve. the apex, erect, clavate, straight for 3/4th of the length, then weakly curved towards the lip, canaliculate ventrally, the ventral flanks ending in distinct angles below the stigma, and with a pair of rather short, lacerate to palmate wings on each side of the stigma, ca. $1.7 \mathrm{~cm}$ long; anther cap white, more or less marked with brown, campanulate, rostrate, dorsally lobulate; pollinarium of two obovoid to pyriform, cleft/folded pollinia on an oblong-rectangular $c a .2 .5 \mathrm{~mm}$ long stipe on a hooked, pulvinate viscidium.

The type plant was originally imported to Europe as "Odontoglossum epidendroides", or possibly " $O$. juninense" (the details were lost with time). The original identification was probably based on similarities to then known Odontoglossum species. Due to legislative complications it has not yet been possible to deposit a type specimen in a Peruvian herbarium (USM) at this time. When, and if, the government of Peru establish the first CITES registered institution in their' country, this issue may be solved in a favorable way.

Additional Records: Peru. Pasco (?): Exact origin unknown but probably from the area near Oxapampa, 


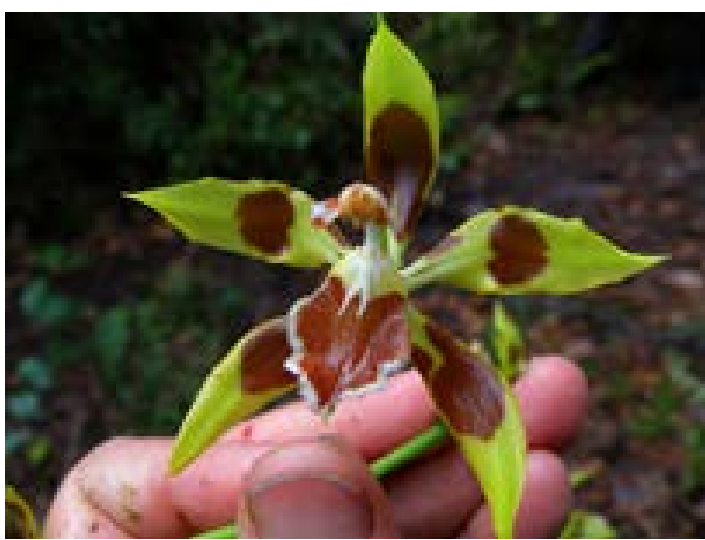

Figure 4. Odontoglossum epidendroides. Photo: S. Dalström.

flowered in cultivation in Palca, Peru, by Manuel Arias, Dec. 2002, S. Dalström 2765 (color transparency in Dalström Archives).

DistRiBution: Recent observations suggest that this species is limited to seasonally wet cloud forests near the town of Oxapampa, Pasco, Peru, at approximate elevations of $2400-2500 \mathrm{~m}$.

Etymology: The name refers to the extraordinarily long and filament-shaped lip callus.

Acknowledgements. The authors thank Wesley Higgins for commenting on the manuscript, Guido Deburghgraeve for cultivating the type plant, and Manolo Arias together with his staff and family in Lima for gracious logistic support. The authors also thank the staff at the Instituto Recursos Naturales (INRENA) for aiding in providing necessary permits, and Betty Millán and Ricardo Fernández at the Universidad de San Marcos, Museo de Historia Natural, Lima, for supporting ongoing orchid research projects and making herbarium material available for studies.

\section{LiTERATURE CITED}

Chase, M. W., N. H. Williams, K. M. Neubig \& W. M. Whitten. 2008. Taxonomic transfers in Oncidiinae to accord with Genera Orchidacearum, vol. 5. Lindleyana in Orchids (West Palm Beach) 77(12): 20-31.

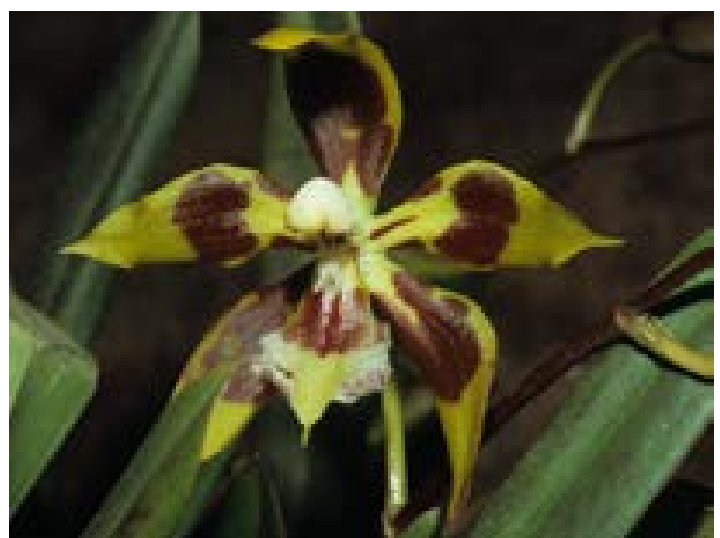

FIGURE 5. Odontoglossum juninense. Photo: S. Dalström.

Chase, M.W. 2009. Subtribe Oncidiinae. In Pridgeon, A.M., M.W. Chase, P.J. Cribb, \& F.N. Rasmussen [eds]. Genera Orchidacearum, Vol. 5. Epidendroideae. Oxford University Press

Dalström. S. 1993. A new species of Odontoglossum (Orchidaceae; Oncidiinae) from Bolivia. Lindleyana 8(1): 15-19.

Dalström. S. 1996. A New Small Flowered Species of Odontoglossum (Orchidaceae; Oncidiinae) of the $O$. astranthum complex from Bolivia. Lindleyana 11(2): $114-117$

Dalström. S. 1999. Anew Bolivian species of Odontoglossum (Orchidaceae; Oncidiinae) in the astranthum complex. Lindleyana 14(2): 87-91.

Dalström. S. 2010. A new species of Odontoglossum (Orchidaceae: Oncidiinae) from Ecuador. Lankesteriana 9(3): 505-508.

Dalström. S. 2012a. New combinations in Odontoglossum (Orchidaceae: Oncidiinae) and a solution to a taxonomic conundrum. Lankesteriana 12(1): 53-60.

Dalström. S. 2012b. A well-known but previously misidentified Odontoglossum (Orchidaceae: Oncidiinae) from Ecuador. Lankesteriana 12(3): 155160.

Dalström. S. 2013. Eine neues, seltsames Odontoglossum as dem Astranthum-Komplex (Orchidaceae: Oncidiinae) der Amazonas-Region in Peru. Orchideenjournal (2): 62-67

Sander, F. 1892. Odontoglossum wattianum. Reichenbachia 1(2), sub Pl. 9. H. Sotheran \& Co., London. 
